\title{
Beragam Peran Media Sosial dalam Dunia Politik di Indonesia
}

\section{The Various Roles of Social Media in Politics in Indonesia}

\author{
Atika Aisyarahmi Munzir, Asmawi \& Aidinil Zetra \\ Jurusan Ilmu Komunikasi, Fakultas Ilmu Sosial dan Poltik, Universitas Andalas, Indonesia \\ Diterima: 30 Juni 2019; Disetujui 12 Agustus 2019; Dipublikasikan 01 Desember 2019
}

\begin{abstract}
Abstrak
Reformasi menjadi momen penting demokratisasi di Indonesia. Dua diantara perubahan penting di bidang politik yang terjadi pada era reformasi yakni kebebasan mendirikan partai politik dan perubahan sistem pemilu. Perubahan tersebut berdampak pada munculnya koalisi dalam dinamika politik di Indonesia, karena pemilihan umum yang dipadukan dengan sistem multipartai tidak mampu menghasilkan suara mayoritas di parlemen. Tulisan ini bertujuan untuk memetakan dan menganalisis dinamika koalisi partai-partai politik di Indonesia pada pemilihan presiden dan wakil presiden era reformasi dengan menggunakan teori-teori koalisi Riker, Katz\&Mair dan Swaan. Dengan Melalui menggunakan pendekatan kualitatif dan pengumpulandan data sekunderdata sekunder yang diperoleh dari pemberitaan media dan literatur, maka ditemukan faktor utama yang memengaruhi terbentuknya koalisi pada pemilihan presiden dan wakil presiden era reformasi. Faktor tersebut adalah pragmatisme politik yang membuat partai politik menjadi partai kartel. Dalam hal ini partai menjadi agen negara dan memanfaatkan sumber daya negara untuk menjaga kelangsungan hidup partai. Pragmatisme inilah yang pada akhirnya menjadikan ideologi bukanlah faktor pengikat dalam membangun sebuah koalisi, namun hanyalah untuk memaksimalkan kekuasaan.

Kata kunci: Pemilu, Partai Politik, Koalisi, Pragmatisme
\end{abstract}

\begin{abstract}
The presence of the internet as a communication and information technology that continues to innovate can give birth to a variety of social media that can be used by an individual for various purposes. Aside from being a means of communicating in cyberspace, social media classified as new media can be used as an effort to present one's self-image including politicians. Now social media can not be separated from the daily life of an individual. Not only as a social need, but the use of social media was able to give influence in the political world. Fast, inexpensive, and effective making social media the most important communication tool in politics. This article aims to discuss the various roles of social media in the political world in Indonesia. The method used is quantitative by identifying the text. The author will use the framing analysis method by taking three research results that explain the various roles of social media in the political world. The results of article writing explain that the role of social media in the political world in Indonesia is as a media campaign, the development of political literacy, and increased voter participation.

Keywords: Social Media, Politics, Political Communication
\end{abstract}

How to Cite: Munzir, A.A. Asmawi \& Zetra, A (2019) Beragam Peran Media Sosial Dalam Dunia Politik di Indonesia. JPPUMA: Jurnal Ilmu Pemerintahan dan Sosial Politik UMA Uournal of Governance and Political Social UMA), 7 (2): 173-182.

\footnotetext{
*Corresponding author:

E-mail: atikaaisyarahmii@yahoo.com
} 


\section{PENDAHULUAN}

Kecanggihan media elektronik yang terus berinovasi dan didukung dengan adanya internet, melahirkan banyak media sosial yang dapat digunakan oleh seorang individu untuk berbagai kepentingan. Selain sebagai sarana berkomunikasi di dunia maya, media sosial yang tergolong ke dalam media baru dapat digunakan sebagai upaya menampilkan citra diri seseorang termasuk para politisi. Penilaian yang dilakukan khalayak terhadap postingan politisi tak jarang menjadi penentu bagaimana kapasitas partisipasi politik seseorang, termasuk partisipasi politik generasi muda yang identik dengan ide-ide kreatif dan kritis.

Banyak sekali varian internet (teknologi digital) yang dimanfaatkan untuk praktik demokrasi, seperti website, blog, media sosial, aplikasi mobile, dan lain sebagainya. Semua varian itu dapat digunakan sebagai alat praktik demokrasi di dunia politik. Misalnya pemilihan umum bisa dilakukan dengan teknologi digital yang akhirnya dikenal dengan sebutan evoting. Para kandidat calon juga bisa menggunakan teknologi digital lainnya sebagai alat sosialisasi atau kampanye. Mereka bisa membuat website dan blog yang berisi profil diri dan program kepemimpinannya jika terpilih nanti. Dukungan publik bisa mereka galang melalui media sosial Facebook, Twitter, Google+, dan lain sebagainya. Para kandidat juga bisa memanfaatkan media Youtube untuk kampanye audio-visual. Kini mereka juga tak perlu mencetak brosur atau mengeluarkan rupiah untuk memasang iklan di televisi yang biayanya jauh lebih mahal. Teknologi digital memberikan sebuah alternatif sebagai sarana kampanye yang murah dan efektif (Andriadi, 2017).

Publik sangat terbantu dengan adanya varian-varian teknologi digital, karena bisa digunakan sebagai sarana partisipasi yang baru. Ada tiga bentuk partisipasi yang bisa dilakukan dengan menggunakan teknologi digital: partisipasi politik, partisipasi kebijakan, dan partisipasi social (Suharyanto, 2016). Media sosial misalnya, dapat digunakan sebagai partisipasi politik. Partisipasi politik berupa aktifitas elektoral (electoral activity) bisa dilakukan dengan menggunakan media sosial seperti Facebook atau Twitter. Misalnya, warga negara bisa turut berpartisipasi dalam kampanye, dan tidak perlu turun ke lapangan. Kualitas kampanye di media sosial bahkan bisa lebih efektif dari kampanye manual yang mengharuskan hadir di lokasi kampanye seperti di stadion (Andriadi, 2017).

Media sosial dalam kehidupan politik di era digital memiliki peran penting. Seperti pada pemilihan presiden AS di tahun 2008, yang menunjukkan kepada dunia bahwa menggunakan jejaring sosial dapat menjadi alat penting dalam melakukan kampanye politik. Di sisi lain, dalam tiga tahun terakhir dunia menyaksikan dua gerakan protes besar dunia yang membuktikan bahwa media sosial bisa menjadi senjata yang kuat di tangan para aktivis politik juga. Dua peristiwa di seluruh dunia ini menunjukkan kepada dunia bahwa pentingnya media sosial dalam menciptakan kesadaran politik dan memobilisasi protes politik (Yunus, 2013)

Sebuah penelitian yang dilakukan oleh We Are Social, memberikan data berupa informasi mengenai media sosial yang populer di Indonesia setiap tahun. We Are Social adalah sebuah perusahaan media dari Inggris dan penelitian ini bekerjasama dengan Hootsuite yang merupakan sebuah situs layanan manajemen konten asal Kanada. Berdasarkan hasil penelitian mereka, media sosial yang paling banyak digunakan di Indonesia saat ini adalah YouTube, Whatsapp, Facebook, Instagram, LINE, Twitter, dan menyusul beberapa media sosial lainnya Fenomena yang menunjukkan strategisnya peran media 
sosial adalah saat Pemilihan Presiden pada tahun 2014. Pada momentum ini, media sosial menjadi primadona. Dua kandidat Calon Presiden Jokowi-Jusuf Kalla dan Prabowo Subianto-Hatta Radjasa sadar ada segmen pemilih khusus, yaitu pemilih pemula dan muda, yang tidak dapat mereka "sentuh" kecuali dengan menggunakan perangkat yang memang mereka minati, yaitu media sosial. Keduanya menyadari pentingnya media sosial sebagai media komunikasi seperti kampanye. Facebook dan Twitter menjadi "kendaraan" komunikasi dan interaksi politik baru para caleg dan parpol dalam menyampaikan visi-misinya. Pada Pilpres 2014 ini, dari total 190 juta pemilih, 11 persen adalah pemilih pemula, sementara pemilih muda di bawah 30 tahun mencapai $30 \%$, dan sebanyak 23\% pemilih belum menentukan pilihannya. Media sosial menjadi semacam "tiket" masuk bagi para kandidat agar bisa diterima di "dunia" pemilih pemula dan muda. Jika para kandidat hanya menggunakan "tiket" konvensional (media konvensional seperti televisi, koran, poster), mereka tidak akan dapat menjangkau pemilih pemula dan muda ini. Oleh sebab itu, peran media sosial akan semakin penting dalam politik. (Andriadi, 2017).

Namun ternyata upaya maksimal yang telah dilakukan para politisi dengan menggunakan media sosial demi mendapatkan perhatian pemilih pemula, tidak akan berjalan sempurna jika generasi muda sudah lebih dulu bersikap apatis dan tidak peduli pada dunia politik. Titi Anggraini selaku Direktur Eksekutif Perkumpulan untuk Pemilu dan Demokrasi mengatakan bahwa anak muda Indonesia memiliki potensi yang baik dalam dunia politik karna mereka mampu bergerak secara dinamis dan berpikir kritis. Influencer Politik Anak Muda (Political Jokes) Herik Kiswantoro menjelaskan bahwa isu politik dianggap bahasan yang sangat serius dan berat sehingga sering tidak menjadi pilihan dalam obrolan anak muda (Kompas 2018). Padahal pada hasil survei Asosiasi Penyelenggara Jasa Internet Indonesia (2017), komposisi utama yang mendominasi pengguna internet di Indonesia adalah usia 19-34 tahun dengan jumlah persentase sebanyak 49,52 persen. Sementara itu, penggunaan media sosial sebagai gaya hidup menduduki posisi pertama dengan persentase sebanyak 87,13 persen. Sedangkan untuk pemanfaatan internet dalam berita politik menempati urutan ketiga setelah berita sosial lingkungan dan informasi agama, dengan perolehan survei sebesar 36,94 persen. Hasil survei tersebut juga memperlihatkan bahwa pertumbuhan pengguna internet di Indonesia mengalami kenaikan setiap tahunnya. Pada tahun 2017, pengguna internet di Indonesia mencapai angka 143,26 juta jiwa dari total populasi penduduk di Indonesia sebanyak 252 juta orang. Dapat disimpulkan bahwa jumlah generasi muda dalam penggunaan media sosial akan terus meningkat. Dan memungkinkan berita politik yang diakses di media sosial dapat memberikan pengaruh pada partisipasi politik generasi muda.

Adanya internet dalam komunikasi politik di Indonesia tentu tidak dapat dihindari. Terdapat faktor-faktor yang menjadi pengaruh terhadap semakin tingginya penggunaan internet dalam komunikasi politik di Indonesia. (Heryanto, 2018); Pertama, internet menjadi sebuah media baru yang lahir di dunia karena merupakan inovasi dan campuran antara media cetak, audio, serta video yang mampu menawarkan komunikasi dua arah. Internet seakan menjadi media komunikasi dan informasi yang tidak dapat dikendalikan oleh siapa pun, termasuk pemerintah yang sedang berkuasa. Kedua, Indonesia juga terpengaruh oleh adanya dinamisasi penggunaan internet yang terjadi di Asia. Dari sepuluh negara di Asia, Indonesia masuk jajaran 4 besar. Dari infografis 4 , 
Tiongkok berada di posisi tertinggi dengan jumlah 731 juta pengguna internet, disusul India 462,70 juta, Indonesia 132 juta pengguna, Jepang 115,10 juta, dan Bangladesh 67,0 juta.

Kemudian yang ketiga, pertumbuhan internet yang cepat di Indonesia. Hasil pemelitian antara Asosiasi Penyelenggara Jasa Internet Indonesia (APJII) dengan Pusat Kajian Komunikasi (PusKaKom) Universitas Indonesia yang dilaksanakan pada tanggal 1 November 2014 sampai 28 Fabruari 2015, menunjukkan bahwa penggunaan internet oleh masyarakat Indonesia akan terus mengalami kenaikan, terutama jika dibandingkan dengan hasil riset APJII sebelumnya yang pernah dilakukan di tahun 2012 (Heryanto, 2018). Berdasarkan pemaparan tersebut, maka artikel ini bertujuan untuk membahas beragam peran media sosial dalam dunia politik di Indonesia.

\section{METODE PENELITIAN}

Artikel ini menggunakan metode kuantitatif dengan cara mengenalisis teks. Peneliti kuantitaif akan menggunakan metode analisis framing. Metode analisis ini sendiri memiliki beberapa pilihan model. Terdapat model Robert Entman, model Zhongdang Pan dan Gerald $M$. Kosicki, model Murray Edelman, dan model William A. Gamson.

Penelitian ini dianalisis dengan menggunakan analisis framing Entman. Pada analisisi Entman, peneliti akan melihat framing dalam dua dimensi besar: seleksi isu dan penekanan atau penonjolan aspek-aspek tertentu dari realitas. Untuk seleksi isu, semua berkaitan dengan pemilihan fakta. Dari hal-hal berupa realitas yang kompleks dan beragam sampai aspek mana yang diseleksi untuk ditampilkan. Dari proses tersebut biasanya selalu terkandung bagian berita yang dimasukkan, tetapi ada juga berita yang dikeluarkan. Tidak semua aspek atau bagian dari isu ditampilkan, dimana peneliti memilih kasus tertentu dari peran media sosial dalam komunikasi politik.

Penulisan artikel ini akan berfokus pada beragam peran media sosial dalam komunikasi politik di Indonesia. Penulis mengambil hasil penelitian dari tiga jurnal penelitian. Alasan pemilihan ketiga jurnal ini didasarkan pada ketiganya menjelaskan berbagai peran media sosial sebagai alat komunikasi politik di Indonesia. Berikut adalah tabel hasil penelitian yang akan dibahas:

Tabel 1. Daftar Peran Media Sosial dan Judul Penelitian

\begin{tabular}{ll}
\hline Peran Media Sosial & Judul Penelitian \\
\hline Media Kampanye & Social Media Sebagai \\
& Media Kampanye \\
& Partai Politik 2014 di \\
& Indonesia \\
Pengembangan Melek & Peranan Media Sosial \\
Politik & Dalam Pengembangan \\
& Melek Politik \\
Peningkatan Partisipasi & Mahasiswa Seran Media Sosial \\
Pemilih & Dalam Peningkatan \\
& Partisipasi Pemilih \\
& Pemula di Kalangan \\
& Pelajar di Kabupaten \\
& Bogor \\
\hline
\end{tabular}

\section{HASIL DAN PEMBAHASAN \\ Media Sosial}

Menurut Nasrullah (2015), media sosial adalah medium di internet yang memungkinkan para penggunanya merepresentasikan dirinya maupun untuk berkomunikasi dan berbagi informasi dengan pengguna lain, dan membentuk ikatan sosial secara virtual. Setidaknya terdapat enam kategori besar untuk melihat pembagian media sosial, yakni: media jejaring sosial (social networking), jurnal online (blog), jurnal online sederhana atau mikroblog (microblogging), media berbagi (media sharing), penanda sosial (social bookmarking), media konten bersama atau Wiki. Pembagian jenis media sosial ke dalam kategori ini merupakan cara untuk mengetahui bagaimana jenis media sosial tersebut. 
Media sosial dinilai mampu menghadirkan cara berkomunikasi baru dengan teknologi yang jauh berbeda dari media tradisional. Berbagai media komunikasi dunia "cyber" ini membentuk jaringan komunikasi yang kaya tanpa batasan ruang dan waktu. Kemudian seiring perkembangan teknologi komunikasi dan informasi, bahkan strategi pemasaran pun mulai beralih menjadi konten marketing. Berbagai peran media sosial pun dijalankan, salah satunya adalah sebagai sarana menebarkan konten yang "eye catching". Tidak hanya konten berupa artikel, namun video, podcast (konten audio), e-book, dan sebagainya juga disebar pada web blog atau situs resmi dan jejaring sosial. Jika media sosial diarahkan ke situs atau blog, kemudian situs tersebut mempersuasi pengunjung untuk menyebarkannya di berbagai jejaring sosial, maka hal itu dapat meningkatkan visibilitas konten (Sulianta, 2017).

Kemunculan media sosial sebenarnya tidak jauh berbeda dengan kemunculan dan cara kerja dari sebuah komputer. Tiga hal yang terjadi, seperti pengenalan, komunikasi, dan kerja sama bisa dianalogikan dengan bagaimana komputer bekerja membentuk sebuah sistem per sistem. Bentuk-bentuk itu merupakan lapisan dimana lapisan pertama menjadi dasar untuk terbentuknya lapisan lain, pengenalan pada dasarnya merupakan dasar untuk berkomunikasi dan komunikasi merupakan dasar untuk melakukan kerja sama (Nasrullah, 2015).

Sedangkan menurut Heryanto (2019), banyak orang yang tidak memperhatikan bahwa media sosial adalah tempat pertukaran pesan yang bersifat one-to-many (dari satu ke banyak orang) bahkan many-to-many (dari banyak orang ke banyak orang). Ketika status atau sebuah narasi muncul pada timeline sebuah akun media sosial, maka pada saat itu pula warga dunia maya (netizen) mampu mengaksesnya. Banyak warga yang bahkan tak peduli pula dengan status-statusnya yang berpotensi melanggar hukum. Banyaknya status yang berpotensi melanggar hukum juga tidak disikapi secara dewasa oleh kelompok yang meresponnya. Tak jarang terjadi pula sebuah perbedaan pendapat yang tidak memperhatikan nilai atau etika.

Hal yang perlu digarisbawahi dari perkembangan internet kini bahwa media baru ini telah pindah dari sekadar media berbasis read-only-web (era web 1.0) menjadi participatory web (era web 2.0) dimana sifatnya telah menjadi user generated content atau yang artinya publik sendiri yang mengkreasi konten. Biasanya dari situ pula akan muncul sebuah fenomena media sosial atau citizen media yang justru mampu melibatkan lebih banyak partisipan. Hal ini lantas akan membuat internet semakin mempunyai peran tersendiri yang cukup penting dan unik dalam dinamika komunikasi politik modern (Heryanto, 2019).

\section{Media Sosial dan Politik}

Menurut Andriadi (2017), evolusi teknologi komunikasi dan informasi telah menciptakan evolusi di dunia politik. Terutama terhadap praktik demokrasi. Di setiap era, praktik demokrasi mengalami perubahan seiring dengan perubahan inovasi teknologi komunikasi dan informasi. Pada era teknologi radio, para politisi menggunakannya sebagai alat kampanye. Publik juga memanfaatkan radio sebagai sarana partisipasi politik. Internet mengatasi kelemahan teknologi era sebelumnya yang hanya satu arah diubah menjadi dua arah (interaktif). Dengan teknologi digital, internet membuat proses komunikasi bisa dilakukan secara interaktif. Dua orang bisa bercakap-cakap seakan seperti berhadaphadapan, padahal berada di dua lokasi yang berjauhan. Sisi interaktifitas inilah yang membuat internet kompatibel dengan demokrasi.

Di negara-negara demokrasi biasanya dianggap bahwa lebih banyak partisipasi 
masyarakat, maka lebih baik. Anggota masyarakat yang turut berpartisipasi dalam proses politik, misalnya dengan memberikan suara atau kegiatan lain, terdorong oleh keyakinan bahwa melalui kegiatan bersama tersebut, maka kepentingan mereka akan tersalur atau sekurang-kurangnya diperhatikan, dan keyakinan bahwa tindakan tersebut dapat memberikan pengaruh pada pihak yang berwenang untuk membuat sebuah keputusan. Dengan kata lain, mereka percaya bahwa kegiatan mereka mempunyai efek politik (Budiardjo, 2017).

Media sosial mulai digunakan secara intensif dalam aspek politik memiliki konteks yang lebih spesifik. Oleh publik, media sosial dijadikan sebagai medium baru untuk mengekspresikan partisipasi politik, sementara bagi para politisi sendiri media sosial menjadi sarana baru dalam menjalin komunikasi, membangun interaksi, dan menyebarkan informasi politis kepada publik (Andriadi, 2017). Media sosial memberikan keleluasaan penuh kepada setiap warga negara untuk mengaktualisasikan partisipasi politiknya. Andriadi (2017) juga menjelaskan bahwa media sosial memberikan ruang alternatif bagi publik untuk mengekspresikan partisipasi politiknya. Salah satu yang paling korelatif dengan fakta ini adalah generasi muda yang memang merupakan segmen sosial paling akrab dengan media sosial.

Selain itu, media sosial dapat memberikan pengaruh terhadap perubahan pemilih di detik terakhir menjelang pencoblosan surat suara calon politisi. Misalnya, yang dilakukan relawan media sosial pasangan Jokowi-Kalla dengan membentuk tim pemantau hasil pemilu dan mengawal surat suara. Relawan pasangan Jokowi-Kalla memanfaatkan media sosial secara optimal untuk melakukan pemantauan dan pengawasan terhadap proses penghitungan suara, sehingga berjalan secara objektif. Ini pembuktian bahwa media sosial memiliki potensi yang besar untuk dimanfaatkan dalam politik praktis. Fenomena dan indikasi yang menunjukkan semakin strategisnya peran media sosial dalam demokrasi di Tanah Air semakin kuat. Peran media sosial akan semakin penting dalam politik. Pelaku politik yang tidak membaca indikasi ini akan kehilangan momentum masa depan demokrasi Indonesia di era digital nanti. Mereka akan tenggelam dalam "lumpur" konvensionalitas politik, hilang ditelan zaman. Tapi jika memanfaatkan teknologi digital, salah satunya media sosial, eksistensi politiknya akan semakin kuat, bisa diterima generasi muda dan pemilih pemula (Andriadi, 2017).

\section{Media Sosial dan Komunikasi Politik}

Dalam komunikasi politik kontemporer, hal yang paling menarik adalah danya fenomena penggunaan media baru (new media), yakni internet digunakan sebagai media atau saluran komunikasi yang semakin sering digunakan masyarakat. Hal ini pun membuat para aktor politik, baik politisi, figur politik, birokrat, aktivis kelompok kepentingan, kelompok penekan, maupun jurnalis media massa, dituntut untuk semakin adaptif dengan penggunaan internet, baik sifatnya yang statis maupun dinamis (Heryanto, 2018).

Melalui penggunaan internet, banyak hal dapat dilakukan dengan waktu yang relatif lebih cepat seperti mendapatkan informasi, sosialisasi gagasan, ajakan, tuntutan, hingga protes dan publikasi usulan alternatif kebijakan. Semua hal jadi terasa lebih efisien dan cepat dibandingkan harus melalui media cetak atau media penyiaran (Heryanto, 2018).

Misalnya, media sosial berperan penting dalam sistem marketing politik di Indonesia, baik untuk pemilu legislatif, pemilu presiden, maupun pemilihan kepala daerah (pilkada) dalam mempromosikan kandidat calon politisi. Kampanye politik tidak lagi sekadar memanfaatkan televisi, koran, majalah, 
radio, tabloid, atau brosur, pamflet, spanduk, tetapi kini juga memanfaatkan media baru yaitu internet (Heryanto, 2018).

Heryanto (2018) juga menjelaskan dalam menyosialisasikan kebijakankebijakan publik dan menciptakan kohesivitas dukungan, lembaga pemerintah, DPR, maupun institusi yudikatif juga telah banyak menggunakan internet. Begitu pun individu maupun kelompok masyarakat yang menyampaikan tuntutan, dukungan ,maupun input politik lainnya, kini dengan leluasa dapat memanfaatkan internet sebagai saluran. Teknik penggunaan internet pun menjadi kian beragam, mulai dari web personal atau institusional yang dikelola secara profesional, blog gratisan, hingga akun di situs-situs jejaring sosial (social network sites).

Dinamika kehidupan sosial politik saat ini menghadirkan akses terhadap dunia informasi yang semakin terbuka. Salah satu penyebabnya adalah kehadiran media baru seperti internet. Media online, terutama media sosial, hadir dengan karakteristiknya yang interaktif dan multimedia. Dalam beragam situasi, para netizen tidak hanya berbagi pesan, tetapi juga menjadikan internet sebagai ruang publik baru (new public sphere). Selain berpotensi menjadi saluran komunikasi yang memberi peran lebih besar kepada netizen, media baru juga kerap menghadirkan sejumlah persoalan dalam pemanfaatannya. Dalam konteks tersebut, literasi media atau literasi politik menjadi sangat penting dan menentukan (Heryanto, 2019).

\section{Peran Media Sosial di Dunia Politik}

Peran media sosial dalam dunia politik yang pertama adalah sebagai media kampanye. Media sosial yang biasanya hanya digunakan sebagai media untuk bersosialisasi dan berkomunikasi dengan teman dan kerabat dekat, kini mulai merambah pada komunikasi antara individu dengan institusi. Media sosial dipandang sebagai suatu alat untuk berinteraksi yang efektif oleh partai politik dan kandidatnya, termasuk untuk mempromosikan produk atau kampanye mereka. Bahkan, menjelang Pemilu Legislatif, Partai Politik mulai semangat membuat akun-akun untuk melakukan kampanye terhadap partai dan caleg mereka. Salah satu contoh peran media sosial sebagai media kampanye adalah saat kampanye presiden Barack Obama tahun 2008 di Amerika Serikat.

Penelitian yang dilakukan Ardha (2014) merujuk pada sebuah survei yang dilakukan oleh APJII pada tahun 2012. APJII menjelaskan bahwa pengguna internet di Indonesia tahun 2012 mencapai 63 juta orang atau setara dengan 24,23 persen dari jumlah total populasi negara Indonesia dan diprediksi akan terus naik. Namun sayangnya, pemanfaatan media sosial seperti facebook dan twitter di kalangan partai politik di Indonesia masih belum optimal. Hal itu dibuktikan dari ke-12 partai politik nasional peserta Pemilu 2014, ada empat parpol yang tidak memiliki akun Twitter resmi, yaitu Partai Amanat Nasional (PAN), Partai Kebangkitan Bangsa (PKB), Partai Persatuan Pembangunan (PPP) dan Partai Keadilan dan Persatuan (PKPI). Namun keempat partai politik tersebut memiliki akun facebook dengan jumlah penyuka yang cukup banyak.

Salah satu keunggulan berkampanye menggunakan media sosial adalah biaya kampanye yang jauh lebih murah. Media sosial juga unggul karena memberi kesempatan kepada para calon pemilih untuk berdialog dua arah dengan kandidat politisi, tidak seperti model kampanye tradisional yang cenderung searah. Sifat komunikasi politik antara kandidat dan calon pemilih bisa menjadi multi arah, seperti dari kandidat ke pemilih, pemilih ke kandidat, atau antar pemilih. Adanya media sosial dapat berperan penting untuk mendongkrak suara secara signifikan bahkan membentuk opini. Munculnya 
opini, berhasil membentuk kekuatan masing-masing calon. Keberadaan kampanye bisa memunculkan secara cepat hal-hal yang berkaitan dengan pergerakan partai politik. Banyaknya pernyataan bisa ikut memengaruhi calon pemilih dalam menentukan siapa yang harus dipilih.

Ardha (2014) menjelaskn meskipun media sosial memberikan pengaruh yang besar sebagai alat kampanye politik, kampanye dapat dikatakan berhasil dengan baik jika dapat memadukan kampanye versi online dan offline. Karena kampanye yang hanya fokus pada media sosial dan internet memiliki kemungkinan tidak akan berjalan secara efektif. Penggunaan media sosial tidak hanya sebagai sarana untuk mempererat silaturahmi, namun juga untuk membahas isu-isu politik, kebijakan pemerintah, dan perilaku para tokoh publik. Media sosial sebaiknya dimanfaatkan dengan baik sebagai sarana komunikasi, atau untuk mempromosikan diri, melakukan sosialisasi, termasuk promosi partai politik dalam membangun citra positif suatu partai. Pemanfaatan media sosial yang efektif dalam berpolitik biasanya akan tampak saat akan diselenggarakannya pemilu untuk kepentingan kampanye politik.

Kedua, media sosial berperan penting dalam pengembangan melek politik masyarakat Indonesia, khususnya generasi muda. Kehadiran media sosial yang banyak digunakan oleh masyarakat termasuk mahasiswa sebagai bagian dari kehidupan sosial politik harusnya dapat dimaksimalkan dengan baik. Namun, adanya berita-berita tidak sesuai fakta dan hal-hal negatif lewat media sosial bisa mempengaruhi bagaimana melek politik mahasiswa menjadi tidak maksimal. Pradana (2017) menjelaskan bahwa media sosial tidak akan bisa dipisahkan dari cara berkomunikasi antar manusia pada era saat ini. Merujuk pada data dari APJII pada tahun 2016, mengindikasikan adanya kenaikan pengguna internet di Indonesia sebanyak 51,8 \% dan jenis konten internet yang paling banyak diaskes sebanyak 97,4 $\%$ adalah media sosial.

Salah satu alasan mengapa melek politik menjadi sentral dalam pembangunan kualitas demokrasi suatau bangsa adalah karena dengan melek politik, maka warga negara akan sadar hak dan kewajibannya sebagai anggota resmi suatu negara. Hal tersebut akan memiliki dampak terhadap timbulnya kesadaran yang otonom dalam partisipasi pembangunan sistem politik dan demokrasi dengan kualitas yang lebih baik. Surbakti (2015) menjelaskan bahwa kesadaran politik yang dimaksud adalah kesadaran akan adanya hak dan kewajiban sebagai seorang warga negara. Hal ini dapat menyangkut pengetahuan seseorang tentang lingkungan masyarakat dan politik, serta menyangkut minat dan perhatian seseorang terhadap lingkungan masyarakat dan politik tempat dia hidup.

Untuk mengetahui bagaiaman peran media sosial terhadap melek politik mahasiswa, Pradana (2017) menggunakan rumus Rank Spearman (Spearman Rank Order Correlation). Dengan menggunakan perhitungan tersebut, diperoleh koefisien korelasi sebesar 0,740. Berdasarkan pedoman interpretasi Guildford yang digunakannya, korelasi 0,740 termasuk pada kategori hubungan yang kuat. Selain hasil perananan media sosial dalam pengembangan melek politik mahasiswa, penelitian ini juga menyimpulkan bahwa penggunaan media sosial oleh mahasiswa sebanyak 48\% termasuk kategori baik, $36 \%$ cukup baik, dan 15\% kurang baik. Sementara melek politik mahasiswa berada pada kategori 36\% baik, 43\% cukup baik, dan 21\% kurang baik.

Peran media sosial yang ketiga adalah meningkatkan partisipasi pemilih, khususnya pemilih pemula. Media sosial yang dijadikan sebagai strategi komunikasi politik merupakan relatif baru dan menjadi fenomena hangat hingga kini. Ratnamulyani dan Basuki (2018) 
menjelaskan bahwa media sosial sebagai sarana komunikasi memiliki peran membawa penggunanya untuk berpartisipasi secara aktif dengan memberi kontribusi dan feedback secara terbuka, baik untuk membagi informasi maupun memberi respon secara online dalam waktu yang tepat. Penelitian yang mereka lakukan pada kasus pemilihan anggota legislatif pada tahun 2014 di Kabupaten Bogor memberikan fakta bahwa ternyata politisi yang ikut berkompetisi dalam pemilihan anggota legislatif kurang memanfaatkan media sosial secara optimal.

Padahal data yang didapatkan dari APJII pada akhir tahun 2013 menjelaskan bahwa pengguna internet di Indonesia meningkat sekitar 20-30 persen dan pertumbuhannya mencapai 33,3\%. Lingkungan telah berubah, yaitu datangnya era baru yang disebut dengan era teknologi digital. Namun gaya kampanya yang dilakukan politisi di Kabupaten Bogor pada pemilihan anggota legislatif tahun 2014 masih bersifat konvensional, daripada menggunakan jejaring internet seperti web site, blog, facebook, twitter, whatsApp, dan sebagainya. Hal inilah yang menjadi salah satu penyebab tingkat partisipasi politik pemilih, khusunya partisipasi pemilih pemula di kalangan pelajar di Kabupaten Bogor yang masih tergolong rendah pada pemilu legislatif 2014.

\section{SIMPULAN}

Perkembangan teknologi komunikasi dan informasi menjadikan media sosial sebagai alat komunikasi yang paling cepat, tepat, dan murah. Bahkan berita di televisi maupun surat kabar yang beredar pun tak jarang mendapatkan informasi lewat media sosial. Dunia politik Indonesia tidak akan pernah lepas dari berbagai pujian, saran, maupun kritik pedas dari seluruh elemen masyarakat Indonesia termasuk pengguna internet (netizen). Kuatnya peran media sosial dalam dunia politik untuk mendapatkan atensi masyarakat lewat kampanye, membantu generasi muda untuk melek politik, dan meningkatkan partisipasi pemilih pemula tidak dapat dihindari. Oleh sebab itu, siapapun yang akan masuk ke dalam dunia politik, perlu memiliki pengetahuan dan keterampilan dalam menggunakan media sosial.

\section{DAFTAR PUSTAKA}

Ambardi, K. (2009). Mengungkap Politik Kartel. Jakarta: Kepustakaan Populer Gramedia.

Ardha, B. (2014). Social Media Sebagai Media Kampanye Partai Politik 2014 di Indonesia. Jurnal Visi Komunikasi. 13 (1): 105-120

Asosiasi Penyelenggara Jasa Internet Indonesia. (2017). Infografis Penetrasi \& Perilaku Pengguna Internet Indonesia 2017. Diunduh di https://apjii.or.id/survei tanggal 30 September 2018

Azed, A.B, (2014). Pilpres di Era Transisi Tahun $1999 . \quad$ Diunduh di http://www.jambiekspres.co.id/berita18609-pilpres-di-era-transisi-tahun1999.html./tanggal 20 April 2019.

Budiardjo, M. (2008). Dasar-Dasar Ilmu Politik. Jakarta: Gramedia.

Budiardjo, M. (2017). Dasar-Dasar Ilmu Politik Edisi Revisi. Jakarta: PT Gramedia Pustaka Utama

Budiatri, A.P. (2018). Personalisasi Partai Politik di Indonesia di Era Reformasi. Jakarta: Yayasan Pustaka Obor Indonesia.

Ekawati, E. (2015). "Koalisi Partai Islam di Indonesia pada Pemilihan Presiden dan Andriadi, Fayakhun. (2017). Partisipasi Politik Virtual Demokrasi Netizen di Indonesia. Jakarta: RMBOOKS

Heryanto, G.G. (2018). Media Komunikasi Politik. Yogyakarta: IRCiSoD

Heryanto, G.G. (2019). Panggung Komunikasi Politik. Yogyakarta: IRCiSoD Kompas. (2018). Suara Generasi Milenial Sangat Potensial dalam Pemilu. Diunduh di https://nasional.kompas.com/read/2018/0 5/07/15570811/sua ra- generasimilineal-sangat- potensial-dalam-pemilu tanggal $10 \quad$ Oktober 2018

Nasrullah, R. (2017). Media Sosial Perspektif Komunikasi, Budaya, dan Sosioteknologi. Bandung: Simbiosa Rekatama Media

Pradana, Y. (2017). Peranan Media Sosial Dalam Pengembangan Melek Politik Mahasiswa. Jurnal Civics. 14 (2): 139-145

Ratnamulyani, I.A. \& Maksudi, I, Beddy. (2018). Peran Media Sosial Dalam Peningkatan Partisipasi Pemilih Pemula Dikalangan 
Atika Aisyarahmi Munzir, Asmawi \& Aidinil Zetra, Beragam Peran Media Sosial Dalam Dunia Politik di

Pelajar di Kabupaten Bogor. Jurnal Ilmu-ilmu Sosial dan Humaniora. 20 (2): 154-161

Suharyanto, A. (2016), Surat Kabar Sebagai Salah Satu Media Penyampaian Informasi Politik pada Partisipasi Politik Masyarakat, Jurnal Administrasi Publik : Public Administration Journal, 6 (2): 123-136.

Sulianta, F. (2015). Keajaiban Sosial Media. Jakarta: PT Gramedia
Surbakti, R. (2015). Memahami Ilmu Politik. Jakarta: PT Gramedia Widiasarana Indonesia

We Are Social dan Hootsuite. (2019). Digital 2019:

Indonesia. Diunduh di

https://datareportal.com/reports/digital2019-indonesia tanggal 18 Februari 2019

Yunus, E. (2013). The Role of Social Media in Creating Political Awareness and Mobilizing Political Protests. Master of Science Thesis. Royal Institute of Technology. 